\title{
Entangling voluntarism, leisure time and political work: the governmentalities of neighbourhood planning in England
}

Article

Accepted Version

Parker, G., Dobson, M., Lynn, T. and Salter, K. (2020) Entangling voluntarism, leisure time and political work: the governmentalities of neighbourhood planning in England. Leisure Studies, 39 (5). pp. 644-658. ISSN 1466-4496 doi: https://doi.org/10.1080/02614367.2020.1763440 Available at https://centaur.reading.ac.uk/90736/

It is advisable to refer to the publisher's version if you intend to cite from the work. See Guidance on citing.

To link to this article DOI: http://dx.doi.org/10.1080/02614367.2020.1763440

Publisher: Taylor \& Francis

All outputs in CentAUR are protected by Intellectual Property Rights law, including copyright law. Copyright and IPR is retained by the creators or other copyright holders. Terms and conditions for use of this material are defined in the End User Agreement.

www.reading.ac.uk/centaur 
Central Archive at the University of Reading

Reading's research outputs online 


\title{
Entangling Voluntarism, Leisure Time and Political Work: The \\ Governmentalities of Neighbourhood Planning in England.
}

\begin{abstract}
Neighbourhood planning was the first volunteer-led statutory planning tool to be created in the UK. Whilst it has provoked debate and critique covering numerous practical and theoretical aspects (Wargent and Parker, 2018), little attention has been paid to the actual experience and motives of the volunteers who spend their leisure time by volunteering to prepare a plan. Given the range of leisure activities that have been shaped in the context of a neo-liberalised policy environment we add to longstanding debates concerning the political nature of leisure and how neo-liberal policies require, and exploit, volunteer time and input while claiming to offer forms of empowerment. Qualitative data derived from neighbourhood plan volunteers is presented here to highlight the political work of neighbourhood planning, thus responding to calls to extend the analysis of the political in and through leisure (Rose et al, 2018). It is argued that neighbourhood planning pushes the boundaries of what can be legitimately asked of volunteers and expected in terms of delivering policy outcomes.
\end{abstract}

Keywords: volunteerism, leisure time, political work, localism, neighbourhood planning, neo-liberalisation, responsibilisation, citizenship. 


\section{Entangling Voluntarism, Leisure Time and Political Work: The Governmentalities of Neighbourhood Planning in England.}

\section{Introduction}

Since the 1990s critical perspectives on volunteering have become more prevalent as active participation in civic society has been used by governments as part of their policy agendas; either to justify existing activity and its claimed benefits, or to populate and enable new forms of voluntarism mobilised through a variety of neo-liberal technologies to 'govern through community' (Rose, 1996; Bulley, 2013). In such political narratives, the enrolment of citizens in a wide range of civic activity as volunteers is often presented as a normative good, and government administrations in the UK over time have constructed volunteering as a core element of 'active citizenship' (Dean, 2015; Moore-McBride et al, 2006) seeking to normalise volunteering in service of public policy.

Increasingly voluntarism has become integral to delivering state policy outcomes (Hancock et al, 2012; Lister, 2015; Williams et al, 2014; UK Government, 2019). The devotion of a significant amount of individual and collective leisure time on the part of those mobilised is required. Efforts made to encourage people to volunteer become entangled in processes of replacing or supplementing state funded work and in this way form part of a variety of neo-liberal strategies (Sager, 2016; Cloke and Johnsen, 2007). Over the past three decades a reliance on contested and value-laden narratives of 'community' and latterly 'neighbourhood' have aided a growing discourse of localism, based on an 'acquiescent' model of citizenship used in order to responsibilise segments of the population. Such political exhortations necessarily involve volunteers spending leisure time progressing various forms of state-invited work. In England this reached its apogee under the 'Big Society' agenda (Such, 2013). As a result, in the UK, volunteers are viewed as essential to fulfil a wide range of civic tasks (Fyfe and Milligan, 2003; DeVerteuil et al, 2019). For Peck and Tickell (2002: p390) this forms part of the mobilisation of 'little platoons' in the service of neo-liberal goals.

The focus here is on the policy of neighbourhood planning (NP) as introduced by the UK Coalition Government in 2010 and formalised via the 2011 Localism Act. The legislation affords communities the right to develop a statutory planning document i.e. the neighbourhood plan. This is of particular interest because neighbourhood planning represents a new iteration of volunteering where the volunteer is both the driver of the activity and the tacit promoter of the policy underpinning the work. The activity is both invited and necessary but it is still subject to manipulation and checking (Parker et al, 2015). This brings into view neighbourhood planning as leisure which is entangled in political service or 
'political work' (cf. Rojek, 2001; Milligan, 2007) and contributes to the debate over both the limits to volunteering and the way in which leisure time has been claimed as a legitimate resource for the realisation of government policy. We contend that such concerns are matters for leisure studies to continue engagement with, particularly where discretionary / leisure time meets the intersections with political work across different activities.

The neighbourhood planning project is utilised here as a case to explore the experience of using volunteers to lead complex work, and where the constraints imposed follow the contours of political power (Grant-Smith and McDonald, 2018; Richter, 2010; Arai, 2004) that can tend towards a parasitical relationship. This responds to recently (re)voiced calls to extend critical leisure studies to confront the intersections of leisure and politics (Rose et al, 2018) and following a longrunning but intermittent strand of attention paid to leisure time and politics over the past 30 years (cf. Wilson, 1988; Bramham, 2006). Thus we add to this agenda by discussing how volunteers and leisure time is being enrolled in neo-liberal political work by exploring in some detail the specific activity involved and the experience of the volunteers themselves.

\section{Leisure Time, Voluntarism and Political Work}

In the UK political parties have called on the population to behave as responsible citizens (Bulley and Sokhi-Bulley, 2014) with associated programmes devised to apply people to deemed morally appropriate tasks. These tropes are key features of neo-liberal ideology and ongoing processes of state-society restructuring, with Fyfe and Milligan (2003: p410) arguing that changes in governance invite a retheorisation of the relationships between the voluntary sector and the state. Specific forms and expressions of power are deployed to shape citizen and volunteer conduct and the governmentalities approach derived from Foucauldian theory has been applied to leisure intermittently to express this approach (e.g. Binkley, 2007; Parker, 2007; Rojek, 2010; Rose et al, 2018).

Within a neo-liberal policy context, appeals to individual and collective forms of volunteering, underpinned by the use of leisure time, raises a range of fundamental questions about the extent to which volunteers are practically capable of addressing welfare needs. Concerns over the role of leisure time in developing citizenship, or reversing the decline of social capital are live issues. The enactment of political work through leisure time requires critical consideration (cf. Urry, 1994; Stebbins and Graham, 2004). Within leisure studies a broader or more diverse research endeavour has been advocated to ensure that the political dimensions of leisure are appraised (Rose et al, 2018). This includes examination of the type of leisure, time devoted, the spaces maintained and the experience of those who participate in volunteering 'opportunities'. Equally progressing research in this way extends leisure studies inquiry into activities that have rarely 
been viewed as 'leisure' or 'volunteering' but which rely on discretionary time to sustain them.

Here we seek to highlight the diversity of leisure activity and experience and raise questions about the granularity of criteria used to recognise volunteering, and the activity actually involved, by arguing that there is a need to recognise both a categorical blurring and attempt to obscure in efforts to mobilise and depoliticise volunteering on the part of governments and in the literature on voluntary organisations. Whilst some accounts have dwelt on issues of volunteer impacts in this context, few have come from within leisure studies, with Such (2013) and Wilson and Musick (1999) as notable exceptions. Instead geographers, sociologists and political scientists have been prominent in extending the scope of such inquiry (e.g. Baillie et al, 2011; Rosol, 2012; Lie et al, 2009; Riley et al, 2013). Within the leisure studies community, the critical leisure and serious leisure perspectives have been advocated as lenses to embrace diverse examples of critical/serious leisure and to creatively link with other theories and concepts (see Veal, 2017; Arai, 2004; Lie et al, 2009). Beyond simply reviewing how these different interdisciplinary traditions have approached this issue from their own perspective, the emphasis here is on bringing into view how leisure can be devised, figured and manipulated to produce outcomes that further political agendas.

In order to achieve 'buy-in' leisure decisions are rationalised through a complex series of messages and inducements intended to activate varying motives and shape expectations, as well as imposing or maintaining constraints. Such mobilisations typically involve a bundling of rhetorical and material devices used to shape volunteer activity (Richter, 2010; Parker, 2007). In this instance these are devised and framed by government with the delivery through volunteers doing the political work necessary for government policy to be successful.

The technologies employed to convince people to volunteer are central to a Foucauldian assessment of neo-liberalised volunteering (Zamora and Behrent, 2016). Discourses of empowerment, through self-help and responsibility, are routinely deployed with the emphasis placed on political responsibility (through politicians and bureaucrats) (Sager, 2012) and social responsibility (through individuals and communities) (Flinders and Moon, 2011); as well as through arguments such as self-enablement (Hustinx and Meijs, 2011) and the impact on the use of leisure time and its entanglement with neo-liberal agendas. Issues regarding the significant periods and levels of unpaid work loom into view here, raising questions about exploitation and the ethical basis of responsibilising people to service government policy objectives (Hustinx, 2008; Hustinx et al, 2010). 
The multiple, overlapping and hybrid nature of leisure reflect a bricolage of motivations and negotiations. Grant-Smith and MacDonald (2018: p560) indicate that genuine volunteering arrangements should be a form of civic participation for the benefit of the community 'even if it also benefits the host organisation and the volunteer'. It is discernible that any given activity can be diverse in terms of motives, inducement and context. This implies a hybridity of motives and sharing of costs and benefits, obligation and return. Lie et al (2009) argue that many forms of volunteering are likely to feature a variety of motives and that in neo-liberal environments pressure to volunteer - to use leisure time - is manifestly apparent and observable; individuals are enrolled to help service governmental agendas relating to shrinking the state, cutting costs and other forms of responsibilisation whilst being motivated by promises of 'empowerment'.

In assessing the organisation and parameters of voluntarism, Fyfe and Milligan (2003) note the 'wide variety of organisational forms, governance structures and activities...[mean that] the boundaries of voluntarism cannot be drawn with confidence' (2003: p398). They cite the 'loose and baggy monster' evocation of volunteering created by Taylor (1992: p171) and apply a series of key features of voluntary activity, which we interrogate in the concluding part of the paper, i.e. whether; the organisation is self-governing; the action is for public benefit; it is independent; it is not for profit; and it is governed by non-paid volunteers.

Questions of definition across these features need further scrutiny given the increasingly fuzzy character boundaries that volunteering operates across, which DeVerteuil et al (2019: p2) regard as 'a series of far-flung and proximate entanglements, relationships and encounters both spatial and social'. Such a relational view also keeps in view how 'some voluntary groups may be independent, [and] many have strong connections with government' (Fyfe and Milligan, 2003: p398), which presents a rather paradoxical situation. Furthermore, when considering the question of governance and control over volunteers, there is a mixed-economy of benefits, constraints on freedom and degrees of control which reflect the unique assemblages and particularised power relations which form attitudes and shape the motives, expectations and behaviours of all parties involved. There are likely to be a range of motivating factors behind the personal decision to volunteer with the a priori perspective of individuals crucial to understanding their motives, calculations and costs as well as the activity involved.

The volunteering types offered affects and attracts those with varying extrinsic motivations for participation, as well as indicating and shaping intrinsic motives, such as altruism (Dean, 2015). This aspect was neglected in the review of Big Society and volunteering produced by Such (2013) which focusses on time and assumptions made about latent reservoirs of time available across society; arguing that the UK government since 2010 have assumed both capacity and 
willingness for people to devote time to voluntary activity. While Such (2013) focuses on the potential reservoir of time available in the population, less attention has been paid to its colonisation through (neo-liberalised) activities.

This is salient because whilst Fyfe and Milligan (2003) highlight how recourse to volunteer effort and the wider voluntary sector has been viewed as somewhat of a 'panacea to many of the problems faced by neoliberal states' (p298), the actual rates of formal and informal volunteering have remained remarkably stable in the UK, raising questions over the ability of government programmes to increase overall levels (NCVO, 2019). Furthermore Low et al (2007) demonstrate that the rates of volunteering vary significantly based on factors of: gender, age, employment status, socio-economic group, education level and locality. These factors are particularly intensified in relation to the distribution of volunteering hours.

Moreover, Rochester (2015) has criticised volunteering research for not explicitly asking whether volunteering and the voluntary sector are compatible with a neoliberal market society. Indeed a considerable body of opinion presents a challenge to the idea that mobilising volunteers is the answer to problems facing liberal democracies (Brown et al, 2000). The argument follows that volunteering 'has been pressed into the service of the state and has been radically changed in the process' (Rochester, 2013: p201).

Concerns about how volunteers and the voluntary sector have been drawn into governmental agendas were highlighted almost thirty years ago in debates about the development of the so-called 'shadow state' (Wolch, 1990), with various reflections and critique regarding how volunteer effort and the voluntary sector was being increasingly enrolled to undertake activity previously performed by the state (Milligan and Conradson, 2006). These critical insights from leisure studies and beyond underpin this study of neighbourhood planning as a form of politicised leisure. We advance this critique in the context of the UK Big Society and localism agenda building out from the Such (2013) paper which omits close scrutiny of the types of activity involved in key planks of that agenda.

\section{Big Society, Localism and Neighbourhood Planning}

The Big Society initiative launched in the UK in 2010 was depicted as involving a 'huge cultural change...where people don't always turn to officials, local authorities or central government for answers to the problems they face' (Cameron, 2010: no pagination). The Conservative party had been airing a refreshed manifesto for government since 2008 and this included: 'fostering and supporting a new culture of voluntarism, philanthropy and social action' (Cameron, 2010: no pagination). It was presented as the opposite of 'big 
government'; a politics of devolution where central government cedes power and responsibility to citizens in neighbourhoods and communities. Here the fusion of neoliberal ideals and collective forms of 'individual' action was expressed through a renewed emphasis on active citizenship at the local and neighbourhood scale, envisaged as '...a society where the leading force for progress is social responsibility, not state control...breaking state monopolies, allowing charities, social enterprises and companies to provide public services, devolving power down to neighbourhoods, making government more accountable' (Cameron, 2010: no pagination).

Individuals and the voluntary and community sector were to be less dependent on the state both financially and by extending their scope of action (Ockenden et al, 2012; Such, 2013). As Lister (2015) indicates the Big Society idea exhibited three strands; social action (i.e. mobilising people as volunteers), reform of the public sector and promoting community empowerment to re-cast the relationship between the state and charities, social enterprises and voluntary and community groups. Ishkanian and Szreter (2012: p4) claimed that Big Society proponents favoured individual citizen-volunteers doing good in their community, organising themselves and taking responsibility for 'sorting out their locality's needs'.

In parallel with the Big Society Agenda, the Conservative-Liberal Democrat Coalition elected in 2010 also rolled-out their localism approach and committed itself to ending an era of top-down government. This shift was voiced repeatedly and memorably by the politician Eric Pickles; 'when people ask me about my priorities in government, I have three very clear priorities: localism, ... My second priority is localism, and my third is...localism' (Pickles, 2010: no pagination). Neighbourhood planning was to be central to this agenda as the flagship policy of the 2011 Localism Act. The government made the claim that neighbourhood planning would allow communities to say where they think new development should go and what it should look like.

Here planning was identified as an area where people 'should' have an active interest. This rationale was underpinned by a confluence of national government agendas centring on the requirement of new development for economic and housing growth which typically faces significant local opposition in England.

Neighbourhood planning represents a form of volunteering where communities are invited to develop their own plan. This involves a considerable amount of unpaid work which, when completed, becomes part of the statutory land use planning system in England. This is significant as it was the first time communityled planning was placed on a statutory footing where the outputs would carry legal weight in land-use planning decisions. Here the Big Society and localism agendas, and particularly neighbourhood planning, have been presented by 
government as offering local empowerment as part of a 'double-devolution' (see Conservative Party, 2008; 2010). However, much critical research and literature view neighbourhood planning as shaped by the aim of 'deresponsibilising' the state through what has been termed a form of 'neoliberal localism' (e.g. Newman, 2014; Peck, 2013). Community groups are incentivised, either in a paternalistic or assertive fashion, to partake in what was perceived in the early modern era as 'dissolving government into society' (Proudhon, 1840) and now as 'governing through community' (Rose, 1996; Brownill, 2017). This has also been classed as a form of 'spatial liberalism' (Clarke and Cochrane, 2013: p29) involved in (re)scaling technologies of agency through volunteers. Thus the 'local' is "increasingly [being] promoted as the key site in and through which freedom and choice can be best deployed to achieve government's ends" (Davoudi and Madanipour, 2013: p559), with volunteers becoming necessary rather than useful or incidental to the delivery of public policy objectives (Lie et al, 2009).

Such government efforts have been labelled as a form of 'muscular localism' pushed by the state (Tait and Inch, 2016), yet the scope for participants to practically effect control over decisions appears quite limited (Parker et al; 2015). Curry (2012) has argued that the complexity of the issues involved and the technical nature of the planning system problematises the participation of 'lay people' in planning. While a large literature has developed on neighbourhood planning (see Wargent and Parker, 2018, for a review and critique), little has been written about neighbourhood planning and volunteering and the quality or legitimate extent of volunteer input to neighbourhood planning. Frustrations regarding the burdensome nature of the process have been reported (Parker et al, 2017). By Autumn 2019 around 2,600 neighbourhoods in England had taken up the activity and around 850 had completed a Plan, with a typical period of three years or more to complete the process (Parker and Salter, 2017; Publica, 2019). Such statistics highlight the amount of effort required and the complex undertaking; involving numerous stages, technical activity and statutory rules to follow (see Locality, 2016). There are a number of assumptions made by government; that communities have the time (Smith et al, 2010), capacity (Mace and Tewdwr-Jones, 2017), and willingness (Davoudi and Madanipour, 2013) to engage.

\section{Methods}

It is argued that activities like community-led planning have not been traditionally thought of as forms of leisure or volunteering, but such activity clearly involves a significant amount of discretionary time and resources for voluntary unpaid work. Neighbourhood planning highlights the entanglement of leisure, voluntarism and political work in England and how leisure time itself is implicated in neo-liberal policy. Such (2013) argues we should ask whose time and how much time are involved. Further than this we argue that a more nuanced investigation about the 
activity involved and the ethical basis for the project need to be queried. To explore these questions individual semi-structured interviews with a sample of 25 core neighbourhood planning volunteers from separate groups involved in the production of a neighbourhood plan were conducted. The qualitative primary data underpinning the findings was specifically organised to explore how the volunteers felt about their NP project and the time invested. The sample was drawn from areas across England who had completed the plan-making stages and could therefore reflect on their experience fully. This approach is justified because the work targeted volunteer time used and maintains Diefenbach's (2009) arguments about how to maintain quality data in semi-structured interviewing, by ensuring that the focus of the questions related directly to issues relating to the time inputs of volunteers.

The interviews allowed respondents to expand on the themes below, which invited comment on the time and resource commitments and the expected knowledge needed (i.e. barriers/limits) of volunteers, as well as the individual and collective motivations and expectations in relation to the outcomes and reflections on their experience as a volunteer. The interviews covered their inputs; how volunteer activities and inputs changed over time; resources available; how the group decided what work should be conducted themselves and which activities needed to be done by professionals; and how the participants evaluated the costs and benefits of their engagement with neighbourhood planning. The data was coded using open and focused coding to create themes based on the responses to the questions. The researcher's initial hypotheses were based on the literature. Overall the approach allows a quite specific set of issues to be elaborated through the sample to highlight key messages regarding the experience of volunteering in neighbourhood planning as expressed across the sample. The topic itself is emotive with volunteers investing heavily in the activity. From the researcher's perspective it was important to elicit views without actively encouraging critique but ultimately crafting what Geertz (1975) termed an 'interpretive account' based on the themes that emerged and using indicative quotes to highlight the themes.

\section{Findings: Leisure Time and Political Work}

The literature has indicated that neighbourhood plans require a significant commitment of both personal and community time and resources particularly for those self-selecting individuals that take part (Parker and Salter, 2017; Parker et al, 2017). In terms of the time and resource commitments, and expected knowledge and skills development necessary for related formalised paid 'work', the appreciation derived from the sample was that the costs associated are high for the volunteer neighbourhood planners. Some interviewees recognised that obstacles were downplayed by government in the early years of neighbourhood planning: 
"I think it was very presumptive of government that neighbourhood planning could be done largely as voluntary effort... it is pretty cheeky to expect that this type of professional work to be done largely through voluntary effort. There is value in community-led experience but places that don't have volunteers of the right skill-set are really going to struggle" (Interview 7).

The volunteers reflected on how the process required much more from them than more traditional forms of voluntary activity outlined in the literature. As one volunteer stated, 'the demands of the neighbourhood planning process have been uneven, it is not like you turn up one day a week at a charity shop - it's not as time bound or specific as that' (Interview 8). This led another to express the "huge differences [of neighbourhood planning] to other voluntary roles' where '[m]ost volunteering (e.g. charity shop, food bank) it is so many hours a week with a regular routine...[that is]..nothing quite like a neighbourhood plan in terms of volunteering" ( Interview 15). A general sentiment expressed by the interviewees was summed up by one volunteer who "thought it would take far less time and commitment than it actually took" and that they had "grossly underestimated [it]... at the beginning [because they] thought it would be simpler than it turned out to be" (Interview 4). These highlight how neighbourhood planning as a form of volunteering dependent on leisure time requires much more than might otherwise be expected of volunteers more broadly engaging within their local community or the third sector.

The participants also voiced concerns over responsibilisation and exploitation, given the activity is led by volunteers who combine it with their other commitments (cf. Lord et al, 2017: p359). It was clear that the volunteers felt that neighbourhood planning became very time-consuming and complex as they progressed through the process, meaning that it became "a 24/7 thing, it became full time very quickly" (Interview 19). Such comparisons with paid work bring into view how leisure time is being colonised in service of a neo-liberal government agenda to engage people in planning and to foster pro-development attitudes; an agenda that is dependent on the political 'work' of volunteers that goes beyond traditional understandings of volunteering. This is justified by a simplistic government assumption that any local voluntary or community engagement and input into policy is a normative good.

Neighbourhood planning requires a significant input of time, but it places other burdens on the volunteers themselves such as pressure from community expectations and forgone leisure time with family and friends. These factors remain hidden or ignored when government promote such policies. Work looking at the links to the 'costs' of engaging in neighbourhood planning may be informed by pre-existing experience of volunteer drop-off rates (e.g. Goss, 1999), which indicates that time costs and frustrations are high and that governments will need 
to deploy numerous tactics to mobilise and retain the volunteer input that this policy relies upon. This means thinking seriously about the agency and particular motivations, expectations, interests and agendas which exist across and amongst volunteers engaged in the process (and within wider society). This goes beyond simply looking at volunteer time inputs, important as this is, but to consider the overall quality of the activity itself.

The volunteers felt external pressure as they were held accountable by their own community for success. Thus, whilst volunteers do not replace paid staff roles in local authorities, as may be the case in other public and voluntary service areas responding to austerity, the issue of what contribution can be legitimately expected from an unpaid volunteer within the process was recognised:

"[neighbourhood planning is a] different species of volunteering. It feels as though I was held more accountable carrying out this role than I have been in other voluntary roles. I have been held accountable by the village; I feel like they don't care whether it's a voluntary role" (Interview 6).

This is particularly salient because those interviewed were members of the "core" group preparing the Plan and many reflected that, although volunteers came forward at the beginning of the process, far fewer stayed the course. This suggests a dual level of volunteering with a core group undertaking the mainstay of planning activity to drive the process forward and maintain its momentum, and a more peripheral group of volunteers acting in the traditional sense with more limited knowledge and buy-in; whereby "some just felt they were doing civic duty and stayed on for the ride but didn't engage too much" (Interview 12). This means that a significant amount of this work is falling on a handful of often retired core volunteers and these findings reflect the challenges they faced.

The volunteers had mixed responses to whether they felt that they had been asked to do too much given the high costs of participation. Some expressed a view that they would expend an unlimited amount of energy, "I care passionately about the area and will never feel like have done too much" (Interview 14). Whilst others were more pragmatic accepting high costs "[as]...a volunteer you don't know how many hours you are going to give in the beginning. We did far more than we were ever going to, but were going to see it to the end no matter what" (Interview 24). This highlights that once a group had started the process and accrued a certain level of 'skin in the game' or sunk costs they would see the process through, but this does not act as a legitimate rationale for the multiple burdens placed on these volunteers to enact state policy.

\section{Findings: Volunteer Motivations and Outcomes}

Given the high personal costs involved in neighbourhood planning, and the need to understand the quality of the activity (rather than simply the quantitative 
measures of take-up and time expended), the motivations of volunteers and their expected outcomes are important.

The neighbourhood planning literature suggests a variety of motives and expectations behind the endeavour, including scope for personal human capital gains; a perception of penalties for non-participation (e.g. unwanted development, poorer quality design or environment, etc); consideration of intracommunity standing or reputation; judgements about the likelihood of a Plan making a tangible difference or whether financial reward might follow - the latter given that incentives to produce a plan have also been present since 2013 (most prominent being the so-called 'Boles Bung', whereby neighbourhoods that produce a neighbourhood plan stand to benefit when new development is completed in the form of a financial bonus of $25 \%$ of Community Infrastructure Levy (CIL) monies (see Brownill and Bradley, 2017). These various motivations and expectations relate back to literature on the wider (personal) altruistic and/or instrumental drivers of volunteering as set against the anticipated outcome(s).

Within this study, the volunteers highlighted a range of intrinsic and extrinsic motivations behind their involvement. It was evident that a number of volunteers were willing to give up their often significant time and resources in exchange for a greater say over local development; this was the 'deal' from government as they understood it. This meant that for them neighbourhood planning was about "taking ownership of improving the village" (Interview 7) and having "protection against what was perceived as inappropriate development" (Interview 13), through having the "local community define planning policy" (Interview 14).

Overall neighbourhood planning was viewed by the volunteers as making the trade-off of their time and resources in exchange for a perceived "[g]reater community input and control over the way planners and the council were seeking to change and develop the local neighbourhood" (Interview 4), and to "ensure that housing develops in keeping with what the community want and not what is bestowed on us" (Interview 6). This raises further critical questions about the level of responsibility placed on a handful of self-selecting core volunteers to undertake statutory work on behalf of a defined community to necessarily deliver on a range of local (long-term) needs. The research and literature on neighbourhood planning has demonstrated that neighbourhood plans rarely have the impact or influence its volunteers envisage, meaning that the reciprocal 'deal' volunteers implicitly make with government is tarnished. This can lead to further distrust of (neoliberal) government public policy agendas that seek to pursue political goals through community involvement and volunteer activity.

In experiencing the process, the volunteers reflected on their initial motivations and expectations that there was an awareness "[p]eople have been misled by 
government statements that it would stop development here" (Interview 13) tinged with a bitterness that they had been 'mis-sold' the effort involved and outcomes achievable. The context for such activity therefore involves a desire not to contribute but to take back control as expressed above. Thus neighbourhood planning becomes a political act for both the participants and of course from government: it is political leisure and leisure as politics simultaneously. This accounts for at least some of the groups' initial motivations:

"[t]here were triggers such as a [development] site coming forward that the residents don't like or could be parking issues...that trigger a group to do it...9 out of 10 people [that] do it are motivated in a reactionary rather than proactive way" (Interview 13).

The volunteers were self-aware that neighbourhood planning differs from other voluntary roles based on the expected returns from their efforts; "normally when people do volunteering, e.g. a driver taking people to hospital if they don't drive, that sort is altruistic. [However there is an] element of self-interest to something like a neighbourhood plan because there was definitely an element of NIMBYism and wanting to protect their garden from being developed" (Interview 10). Beyond the more overt primary motives behind volunteering there were a number of other reasons for engagement such as "personal interest" (Interview 24). For example, one participant was a local government officer who wanted to gain experience for his career; another was a professional researcher new to the area who wanted to get to know the place and people; another had just retired and saw this as "an opportunity to try and make a contribution" (Interview 10).

Despite this, regardless of their initial motivations, it was noted that the length of the process actually provided the time and space acting in an environment for some volunteers to cultivate social learning and engagement over more socialcollectivist issues (such as providing affordable housing and promoting sustainability), even if they first engaged with NP from an instrumental mindset. For example, one participant reflected that even though their engagement with neighbourhood planning was self-motivated, overtime it "actually became more of a project - let's get this neighbourhood plan and make a better community" (Interview 24). However, only a handful of core volunteers actually remain involved in the process to potentially benefit from this level or transformation of contribution. Again this raises questions about the benefits and learning of the other volunteers who are more superficially engaged in the process and whether their involvement instead acts to window dress a policy vehicle that can obscure dissatisfaction over planned outcomes, rather than necessarily resolve them.

The expected outcomes of their time, resources and effort with the assessment of the likelihood of making a difference locally is also dependent on the extent of the difference sought and the ambition of the Plan (Mace and Tewdwr-Jones, 
2017: p6). However, unlike other forms of participation and voluntary activity, neighbourhood planning is one in which volunteers can continually and objectively fail throughout the process; given that neighbourhood plans are formally assessed and 'examined'. Volunteers are judged on the Plan as an outcome and not only the intentions or effort involved. Furthermore volunteer effort in service of neighbourhood planning, once a Plan has been completed, does not guarantee any measurable difference in planning outcomes in relation to local decision-making, and the process does not simply end there. For one volunteer, the "outcome of [their] plan since adoption has been less successful because the local authority cannot demonstrate 5 year [housing land supply] plan" and had already lost two appeals which undermined the hopes of the plan to "achieve more" (Interview 3). As an activity, volunteers have the expectation that the Plan will produce results along the lines of governmental rhetoric. Some volunteers saw that this was not matched with their experience, with one stating "we have got a Plan adopted last June - has it made any realistic difference? No" (Interview 17).

While the wider volunteer literature suggests that 'the benefits of volunteering often come through intrinsic motivation (to complete the voluntary act) rather than extrinsic motivation (to gain an identified benefit)' (Dean, 2015: p141), this case raises potential challenges for volunteering. Successive UK governments are promoting neo-liberal policies designed to harness community actors to fulfil state goals, without actually making the experience of volunteering more manageable or ensuring it is impactful for those mobilised. Neighbourhood planning is often embarked upon, at least initially, for the extrinsic motivation of producing a statutory land-use document. It is as a means to exercise 'control' over local development, without which the volunteer may feel little other 'altruistic' motivation or benefits towards their efforts if their expectations are then not achieved.

These findings highlight a significant level of responsibility (responsibilisation) being taken on by neighbourhood planning volunteers to deliver a plan for the future of their locality that meets the national and local government requirements (basic conditions) while attempting to represent the myriad interests of their community.

\section{Discussion and Conclusion}

This reading of neighbourhood planning contributes to the literature on leisure politics in several ways. Firstly, to expose the political work that is being done using leisure time; and secondly, to highlight how characteristics of voluntarist activity and organisations require a finer grain of analysis in order to understand the claims made against behaviours and conditions. There is also a third and wider reflection derived from this research involving the neoliberal colonisation of 
leisure time. This invites reflection over the pervasive nature of neo-liberal governmentalities and its importance given the leisure politics research agenda as recapitulated by Rose (2018). This agenda embraces the extension of leisure studies inquiry into activities that have rarely been viewed as 'leisure' or 'volunteering', but which rely on discretionary time to sustain them.

This highlights an ongoing need to examine the neo-liberalisation of leisure and volunteering as leisure, where the individual is invited to participate in political work offered up as good citizenship, or in order to affect local outcomes. The case of neighbourhood planning has highlighted a multiplicity of volunteer side rationalities and these need to be set against the technologies deployed by government to mobilise such volunteering and the high costs of involvement. What is at stake politically, and tangibly, needs to be considered critically, particularly given the questionable likelihood of the Plan meeting volunteer expectations. Such analyses show how volunteers can be entangled in state-led forms of 'roll-out' neoliberalism which reach into the individual / personal sphere and how their acceptance forms part of an unbalanced political trade-off.

Given that the likelihood of 'success' is defined by volunteer motivations and government agenda to boost housing and development, and is questionable, the promises and relationship between inputs and output and between governmental technologies arranged to induce participation are necessarily held up for scrutiny. Reflecting prior research on neighbourhood planning, the 'return' anticipated by volunteers lies in the promise of wresting back some degree of control over local planning decisions. Within our findings there are degrees of instrumentalism and rational choice expressed where participatory activity becomes part of a political act on the part of the volunteer.

The first contribution of this study is therefore to highlight how political work is being promoted by government and undertaken by volunteers using their leisure time. This highlights a view expressed by Brown et al. (2000: p.57) that regards opportunities presented by government for communities to take responsibility as 'place[s] where politics can be democratized, active citizenship strengthened, [and] the public sphere reinvigorated'. Yet such a perspective downplays unresolved issues of motives, willingness, coercion, bounding and costs, as well as the benefits of participation, as discussed by Cloke and Johnsen (2007). This study highlights the need to pay more attention to the granularity of issues involved to help present a clearer focus on assessing the basis for legitimate volunteering activities and the limits to 'voluntarism'.

Drawing on conceptualisations of volunteer involvement as either unstructured or structured, neighbourhood planning may be placed as an example of structured activity also labelled 'civic service' (Moore McBride et al, 2006). Those involved 
are directed to a particular output following certain boundaries. In this instance a statutory planning process (see Bradley, 2015), with the endeavour supposed to reflect a wider public interest. However, the methods and means to get a Plan in place is unstructured and somewhat ambiguous, adding further burdens of uncertainty on volunteers. These 'unknowns' associated with neighbourhood planning are manifest in terms of the process of engagement, the negotiations involved and the outcomes.

The findings presented here also leads us towards a deeper consideration of volunteering and how individuals are performed. The criteria for assessing organised volunteering needs to be further developed across activities where volunteer time is expended. Particularly where this has become entangled with governmental agendas. Given this emphasis, the second contribution of the paper is to develop the critique of assumptions typically applied to voluntarist activity and organisations. This also invites a finer grain of analysis in order to understand the claims made against citizen behaviours and conditions of actually existing practice. Renewed interest in these issues shown by DeVerteuil et al (2019: p1) is an analytical step forward, but we argue that we need to bring not just the voluntary sector 'out of the shadows', as they press for, but also the actual volunteers and activities which are still missing in such accounts. This goes back to Such's (2013) work that effectively evaluates what is expected of the third sector and volunteers under Big Society but with no specificity of the actual activities being taken on by volunteers. Indeed very few studies have sought to evaluate specific forms of voluntary activity. This has been done here using the case of neighbourhood planning. We argue that this can provide an example of a more fine-grained analysis that moves beyond general considerations of the type and time spent on voluntary activities to one that evaluates the quality and outcomes of such experiences. The final paragraphs in this paper take Fyfe and Milligan's (2003) five characteristics in turn to highlight the complexities of this one specific form of voluntary activity.

- Self-Governing - the issue of whether neighbourhood planning groups are 'selfgoverning' may underplay the backstage power plays and more overt limits placed on organisations by those holding power and resources. This has particular import as the resourcing and limits of operation become further controlled by external funders and governmental regulation and the input of private consultants to make them compliant with these ends.

- Public Benefit - there is a question mark over whether the voluntary activity is actually for public benefit. The motives expressed in our study are mixed and while some reflect rationales about altruism (as also expressed by government) others have a mix of intrinsic and extrinsic motivations, exposing the idea of a wider 'public' which requires careful attention, particularly when contrasted to that of a narrower community interest. The neighbourhood planning agenda invites 
volunteers to think about their own small patch and can therefore foster a parochial view that primarily serves the interests of those directly involved in the process. It is unlikely those most disadvantaged will participate in the process (see Parker and Salter, 2017). Here it is moot whether it is socially and morally appropriate to base a policy which can affect lived environments on agency which is highly uneven in depth and geography.

- Independence - whether the neighbourhood planning process can be considered as 'independent' is debatable, in the sense of being community and volunteer-led. Given its technical and political nature, volunteer reliance on funding from government, and the significant inputs from the local authority, consultants and other actors are necessary to navigate the production (and implementation) of the Plan.

- Non-Profit - whether neighbourhood planning can be considered 'not for profit' in the traditional understanding of not involving financial or monetary gain from such activities is also contestable. There is little doubt that local people involved are not seeking to profit directly, but in terms of benefit those engaged in neighbourhood planning may seek this from their efforts through different means, such as having more control over housing development in their neighbourhood. Their time and effort is returned through the promise of greater influence over local planning decisions (whether this is in line with their expectations or not).

- Run by Unpaid Volunteers - neighbourhood planning can certainly be accepted as being governed by non-paid volunteers who commit a significant amount of their time and resources into such activities. This is comparable to the effort expended for paid work and activities that provide more direct remuneration. However, the work of neighbourhood planning is in reality a co-produced effort with critical control withheld by central government and significant levels of influence held by local authorities. Thus, taken together, the orthodox view of voluntary organisations becomes far more open to question than has been revealed in the past. Overall this highlights the greying of such activity as groups seek to mobilise communities and where paid consultants are often used to assist the volunteer groups.

We contend that, on a surface level, it appears that neighbourhood planning meets these five criteria for voluntary activity; however, when adopting a more fine-grain analysis it becomes clear that there are a number of critical questions and issues around its status as a legitimate voluntary activity.

Deeper reflection is needed on the qualities as well as availability of volunteer / leisure time within society (cf. Such, 2013). When one considers how time is being appropriated to service particular political agendas there are three active elements which require attention: the terms (inducement, responsibilisation, 
scope), the activity itself (pressures, burdens, dynamics) and the outcomes (promise, motives, use). Here whether the volunteering space corresponds to the five categories becomes secondary to questions of the legitimacy of the terms of the deal in moral and ethical terms.

In addition to the established features applied above, the case also precipitates more consideration of the specifics of the activity, the time inputs involved and more widely the ethical basis for using volunteers to pursue governmental agendas. This leads us to posit a sixth category concerned with equity; a consideration of the credentials of the activity based on whether it is fair and legitimate to make claims on volunteer time. This is made more apparent where the inputs are high and outcomes uncertain.

Our reading is that there must be limits to how and where governments seek to mobilise volunteers, as well as adhering to more basic boundaries and transparencies. It seems clear that too much has been expected of individuals in neighbourhood planning so far. Moreover the goals of the state in political and ideological terms have been prioritised above the activity and experience of the volunteer upon which the project relies and on whom its continued existence depends in the future. The burdens involved bring into question the legitimacy of such activity. Indeed other forms of voluntary activities may be put under this type of scrutiny and be found to exhibit similar questionable terms, activity and outcomes which will advance understanding of volunteering and its (neo-liberal) entanglements with politicised leisure activity.

\section{Funding}

We wish to acknowledge that the primary data underpinning this paper was supported through a

\section{References}

Arai, S. (2004) 'Volunteering in the Canadian context: identity, civic participation and the politics of participation in serious leisure', pp 151-176 in Stebbins, R. and Graham, M. (eds.) Volunteering as Leisure/Leisure and Volunteering. $\mathrm{CABI}$, Wallingford.

Binkley, S. (2007) 'Governmentality and Lifestyle Studies, Sociology Compass, 1(1):111-127.

Bradley, Q. (2015) 'The political identities of neighbourhood planning in England', Space and Polity, 19(2): 97-109.

Bradley, Q. and Brownill, S. (2017) 'Localism and Neighbourhood Planning' (eds.) Policy Press, Bristol. 
Bramham, P. (2006) 'Hard and Disappearing Work: Making Sense of the Leisure Project', Leisure Studies, 25(4): 379-390.

Brown, K., Kenny, S., Turner, B. and Prince, J. (2000) Rhetorics of Welfare: Uncertainty, Choice and Voluntary Associations. London, Macmillan.

Bulley, D. (2013) 'Producing and governing community (through) resilience', Politics 33(4): 265-275.

Bulley, D. and Sokhi-Bulley, B. (2014) 'Big society as big government: Cameron's governmentality agenda', The British Journal of Politics \& International Relations, 16(3): 452-470.

Cameron, D. (2010) 'The Big Society' Speech delivered $19^{\text {th }}$ July 2010. Accessible at: https://www.gov.uk/government/speeches/big-society-speech (last accessed 9th August 2019)

Clarke, N. and Cochrane, A. (2013) 'Geographies and politics of localism: The localism of the United Kingdom's coalition government', Political Geography, 34(1): 10-23.

Cloke, P. and Johnsen, S. (2007) Ethical citizenship? Volunteers and the ethics of providing services for homeless people', Geoforum, 38(6): 1089-1101.

Conservative Party, The (2008) A Stronger Society: voluntary action in the 21st century. Conservative Party, London.

Curry, N. (2012) 'Community Participation in Spatial Planning: Exploring Relationships between Professional and Lay Stakeholders', Local Government Studies, 38(3): 345-36.

Davoudi, S. and Madanipour, A. (2013) 'Localism and Neo-liberal governmentality', Town Planning Review, 84(5): 551-561.

Dean, J. (2015) 'Volunteering, the market, and neoliberalism', People, Place and Policy, 9(2): 139-148.

Deverteuil, G., Power, A. and Trudeau, D. (2019) 'The Relational Geographies of the Voluntary Sector: Disentangling the Ballast of Strangers', Progress in Human Geography: online pp1-19.

Diefenbach, T. (2009) 'Are case studies more than sophisticated storytelling?: Methodological problems of qualitative empirical research mainly based on semi-structured interviews'. Quality \& Quantity, 43(6): 875.

Flinders, M. and Moon, D. (2011) 'The problem of letting go: The 'Big Society', accountable governance and 'the curse of the decentralizing minister'. Local Economy, 26(8): 652-662.

Fyfe, N. and Milligan, C. (2003) 'Out of the shadows: exploring contemporary geographies of voluntarism', Progress in Human Geography, 24(7): 397-413. 
Geertz, C. (1975) The Interpretation of cultures. Hutchinson, London.

Goss, K. (1999) 'Volunteering and the Long Civic Generation', Non-profit and voluntary Sector Quarterly, 28(4): 378-415.

Grant-Smith, D. and McDonald, P. (2018) 'Ubiquitous yet Ambiguous: An Integrative Review of Unpaid Work', International Journal of Management Reviews, Vol. 20, 559-578.

Hancock, L., Mooney, G. and Neal, S. (2012) 'Crisis social policy and the resilience of the concept of community', Critical Social Policy, 32(3): 343-364.

Hustinx, L. (2008) 'I quit, therefore I am', Nonprofit and Voluntary Sector Quarterly, 39(2): 236 - 255.

Hustinx, L., Cnaan, R. and Handy, F. (2010) Navigating Theories of Volunteering: A Hybrid Map for a Complex Phenomenon, Journal for the Theory of Social Behaviour 40(4): 410-434.

Hustinx, L. and Meijs, L. (2011) 'Re-embedding volunteering: In search of a new collective ground'. Voluntary Sector Review, 2(1):5-21

Ishkanian, A. and Szreter, S. (2012) The Big Society Debate: a new agenda for social policy? Cheltenham, Edward Elgar.

Lie, M. (2009) 'Citizenship, Volunteering and Active Ageing' Social Policy and Administration, 43(7): 702-718.

Lister, M. (2015) 'Citizens, Doing It for Themselves? The Big Society and Government through Community', Parliamentary Affairs, 68(2): 352-370.

Locality (2016) Neighbourhood Planning Roadmap. Locality, London.

Lord, A., Mair, M., Sturzaker, J., and Jones, P. (2017) 'The planners' dream goes wrong?' Questioning citizen-centred planning. Local Government Studies, 43(3): 344-363.

Low, N., Butt, S., Ellis, P. and Smith, D. (2007) Helping out: a national survey of volunteering and charitable giving. London: Cabinet Office.

Mace, A., and Tewdwr-Jones, M. (2017) 'Neighborhood Planning, Participation, and Rational Choice', Journal of Planning Education and Research. 39(2): 184193.

Milligan, C. (2007) 'Geographies of voluntarism: mapping the terrain'. Geography Compass, 1(2): 183-199.

Milligan, C. and Conradson, D. (2006) Landscapes of Voluntarism. Bristol, Policy Press. 
Moore-McBride, A., Brav, J., Menon, N. and Sherraden, M. (2006) Limitations of civic service: critical perspectives, Community Development Journal, 41(1):

307-320.

NCVO (2019) 'How many people volunteer and what did they do?' Located at: https://data.ncvo.org.uk/volunteering/ [last accessed $12^{\text {th }}$ Nov 2019]

Newman, J. (2014) Landscapes of antagonism: Local governance, neoliberalism and austerity', Urban Studies, 51(5): 3290-3305.

Ockenden, N., Hill, M. and Stuart, J. (2012) The Big Society and volunteering: ambitions and expectations. The Big Society Debate: A New Agenda for Social Policy?, p.149.

Parker, G. (2007) The Negotiation of Leisure Citizenship: Leisure Constraints, Moral Regulation and the Mediation of Rural Place', Leisure Studies, 26(1): 1-22.

Parker, G., Lynn, T. and Wargent, M. (2015) Sticking to the script? The coproduction of neighbourhood planning in England. Town Planning Review, 86(5): 519-536.

Parker, G., Lynn, T. and Wargent, M. (2017) Contestation and conservatism in neighbourhood planning in England: reconciling agonism and collaboration? Planning Theory \& Practice, 18(3): 446-465.

Parker, G., and Salter, K. (2017) 'Taking Stock of Neighbourhood Planning in England 2011-2016', Planning Practice and Research, 32(4): 478-490.

Peck, J. (2013) 'Explaining (with) Neoliberalism', Territory, Politics, Governance, 1(2): 132-157.

Peck, J. and Tickell, A. (2002) 'Neoliberalizing space' Antipode, 34: 380-404.

Publica (2019) The State of Neighbourhood Planning 2018/2019. Located at https://www.trustforlondon.org.uk/publications/state-neighbourhood-planninglondon-201819/

Richter, A. (2010) 'Exploiting an 'army of friendly faces': volunteering and social policy implications', Journal of Policy Research in Tourism, Leisure and Events, 2(2): 184-188.

Riley S., Griffin C. and Morey Y. (2013) The Rise of the "Pleasure Citizen": How Leisure Can be a Site for Alternative Forms of Political Participation, pp61-75 in Demetriou K. (ed.) Democracy in Transition. Berlin, Springer.

Rochester, C. (2013) Rediscovering Voluntary Action. Basingstoke Palgrave Macmillan.

Rochester, C. (2015) 'Critical thinking about voluntary action and its history'. Located at: http://www.vahs.org.uk/2015/02/critical-thinking-about-voluntaryaction-and-itshistory (last accessed $22^{\text {nd }}$ July 2019) 
Rojek, C. (2001) 'Leisure and Life Politics', Leisure Sciences, 23(2): 115-125.

Rojek, C. (2010) The Labour of Leisure. London, Sage.

Rosol, M. (2012) 'Community volunteering as neoliberal strategy?

Green space production in Berlin', Antipode, 44(1): 239-257.

Rose, N. (1996) 'Governing advanced liberal democracies', pp.144-161 in Sharma, A. and Gupta, A. (eds.) The Anthropology of the State: a reader. Oxford, Blackwell.

Rose, J., Harmon, J. and Dunlap, R. (2018) ‘Becoming Political: An Expanding Role for Critical Leisure Studies', Leisure Sciences, 40(7): 649-662.

Sager, T. (2012) Reviving critical planning theory: Dealing with pressure, neoliberalism, and responsibility in communicative planning. London, Routledge.

Sager, T. (2016) 'Activist planning: a response to the woes of neo-liberalism?' European Planning Studies, 24(7): 1262-1280.

Smith, F., Timbrell, H. and Woolvin, M. (2010) 'Enlivened geographies of volunteering: Situated, embodied and emotional practices of voluntary action', Scottish Geographical Journal, 126(4): 258-274.

Stebbins, R. and Graham, M. (eds.) (2004) Volunteering as Leisure / Leisure as Volunteering. Wallingford, CABI.

Such, L. (2013) 'Little leisure in the Big Society', Leisure Studies, 32(1): 89-107.

Tait, M. and Inch, A. (2016) 'Putting Localism in Place: Conservative Images of the Good Community and the Contradictions of Planning Reform in England', Planning Practice and Research, 31(2): 174-194.

Taylor, M. (1992) The changing role of the non-profit sector in Britain: moving toward the market, pp147-175 in Gidron, B. (ed.), Government and third sector, San Francisco: Jossey-Bass.

UK Government (2019) 'Volunteer'. Located at: https://www.gov.uk/government/get-involved/take-part/volunteer (last accessed 24th June 2019)

Urry, J. (1994) 'Culture change and contemporary tourism', Leisure Studies, 13(4): 233-238.

Veal, A. (2017) 'The Serious Leisure Perspective and the Experience of Leisure' Leisure Sciences, 39(3): 205-223.

Wargent, M. and Parker, G. (2018) 'Reimagining neighbourhood governance: the future of neighbourhood planning in England', Town Planning Review, 89(4): 379-402. 
Wilson, J. and Musick, M. (1999) 'The effects of volunteering on the volunteer', Law and Contemporary Problems, 62(4):141-168.

Williams, A., Goodwin, M. and Cloke, P. (2014) 'Neoliberalism, Big Society, and progressive localism', Environment and Planning A: Economy and Space, 46(12): 2798-2815.

Wilson, J. (1988) Politics and Leisure. London, Routledge.

Wolch, J. (1990) The Shadow State. London, Unwin Hyman.

Zamora, D. and Behrent, M. (eds.) (2016) Foucault and Neoliberalism. Cambridge, Polity Press. 